\title{
PEMANFAATAN PUISI SEBAGAI SUMBER BELAJAR IPS UNTUK MENUMBUHKAN KESADARAN LINGKUNGAN PESERTA DIDIK \\ DI SMP NEGERI 6 BANJARMASIN
}

\author{
Oleh: Mutiani
}

\begin{abstract}
Abstrak
Permasalahan krusial krisis ekologi yang terjadi di Kalimantan Selatan, yakni: eksploitasi ruang, eksploitasi Pegunungan Meratus, dan kerusakan Sungai. Tentunya, krisis ekologi dapat diatasi dengan cara menumbuhkan nilai kesadaran lingkungan melalui pendidikan tanpa terbatas pada jenjang sekolah. Pendidikan IPS sebagai mata pelajaran di jenjang sekolah dasar, menengah dan atas mengususng misi secara utuh melihat persoalan manusia tidak hanya dari segi perilaku tetapi juga dalam persfektif yang lebih luas yaitu kehidupan sosial dan alam. Keselarasan Pendidkan IPS dalam merespon krisis ekologi yang terjadi di Kalimantan Selatan dapat dapat dilihat dari sumber belajar puisi. Puisi bertemakan lingkungan yang diciptakan oleh penyair Kalimantan Selatan mendeskripsikan bagaimana fenomena lingkungan terjadi. Fenomena lingkungan ini patut dipahami oleh peserta didik sehingga mereka dapat menjadi agen perubahan dalam menghadapi permasalahan lingkungan. Puisi yang merupakan bagian dari karya sastra imajinatif memiliki makna yang patut diekplorasi untuk kepentingan pendidikan, tanpa terkecuali pada mata pelajaran IPS. Berkenaan dengan hal tersebut maka peneliti menggabungkan pendekatan sastra dengan IPS sebagai sebuah kajian guna memperkaya sumber belajar IPS. Dengan demikian, Puisi sebagai sumber belajar IPS relevan digunakan oleh guru IPS untuk memberikan inovasi pembelajaran IPS yang lebih komunikatif dan menarik di kelas. Kata Kunci: Krisis Ekologi, Puisi, dan Sumber Belajar IPS
\end{abstract}

\section{A. Pendahuluan}

Kerusakan lingkungan seharusnya dapat diminimalisir dengan cara mengendalikan keserakahan manusia dalam mengeksploitasi alam. Manusia harus ditempatkan sebagai bagian dari alam dan bukan sebaliknya terpisah dari alam. Manusia tidak lagi menjadi makhluk alami yang menggantungkan hidupnya pada alam, sebaliknya manusia menjadi faktor penentu keberlangsungan alam. Cara pandang ini menunjukkan ancaman tersembunyi saat manusia mencapai level tertinggi dalam pengelolaan alam yaitu proses eksploitasi alam. Tanpa disadari lambat laun proses itu menjadi ancaman terhadap munculnya berbagai bencana alam sebagai akibat ulah manusia. Peran manusia semakin menunjukkan kekuataannya yakni menjadi "pengendali alam". Paradigma ini dikenal dengan istilah antroposentris, yang menempatkan manusia sebagai "dewa" dan pengatur alam. Paradigma antroposentris diimplementasikan dalam bentuk intervensi manusia terhadap alam untuk memenuhi kebutuhan hidupnya yang seringkali menimbulkan disfungsi keseimbangan alam dan mendiskreditkan peran alam sebagai elemen 
kehidupan yang memiliki hak perlindungan (Costanza, 2007 hlm. 522; Domanska, E 2010 hlm. 118; Kahn, 2008 hlm. 8).

Konten Pendidikan Lingkungan Hidup dapat diintegrasikan dalam mata pelajaran, tanpa terkecuali IPS (Social Studies). Mata pelajaran IPS yang disajikan sebagai bentuk penyederhanaan ilmu-ilmu sosial dan humaniora, seperti: Sejarah, Geografi, Ekonomi, Sosiologi, Antropologi, hingga Pendidikan Kewarganegaraan yang dirangkum dengan tujuan memberikan kesadaran bagi peserta didik sebagai warga negara yang bertanggung jawab tidak hanya sesama manusia, institusi (negara), tetapi juga alam sekitarnya (Gross, Messick, dkk., 1978, hlm. 3). Tujuan ini menjadi tantangan yang menuntut guru IPS untuk memiliki kecakapan dalam meramu pembelajaran yang efektif dan menarik. Strategi pencapaian mutu pembelajaran sangat dipengaruhi oleh berbagai faktor yang kerap muncul saling berkaitan dan bersamaan dengan perubahan dinamisasi perkembangan masyarakat itu sendiri. Oleh karena itu, guna memaksimalkan strategi pembelajaran dapat dilakukan dengan memanfaatkan masalah lingkungan hidup sebagai tema dari pokok bahasan pembelajaran (Farris, 2012, hlm. 23; Almuchtar, 2008, hlm. 37; Maxim, 2010, hlm. 14-15).

Puisi merupakan karya sastra dengan klasifikasi dokumen atau bahan cetak dapat dijadikan sebagai alternatif pilihan sumber belajar bagi guru IPS. Sastra yang terkandung dalam puisi dijadikan sebagai forum yang sengaja diciptakan manusia (penyair) untuk memenuhi tuntutan kebutuhan batiniah dan sekaligus sebagai ajang atau media mengungkapkan cita, karsa, dan karya (Rusyana, 1984, hlm. 27). Puisi yang diciptakan oleh sastrawan ataupun penyair selalu memiliki nilai dan makna yang ingin disampaikan kepada pembaca. Nilai dan makna tersebut, dapat diajarkan pada mata pelajaran IPS. Meskipun pamanfaatan puisi sebagai sumber belajar IPS bermanfaat dan sangat potensial tetapi, dalam praktiknya sumber belajar puisi sangat jarang digunakan. Ditambahkan oleh Farris bahwa integrasi IPS dan seni adalah sebuah kombinasi yang menakjubkan bagi peserta didik sebab keduanya memiliki esensi sama yaitu saling mengikat, mengisyaratkan, dan merayakan fenomena kehidupan. Penyampaian isu lingkungan yang tertera pada puisi, diharapkan mampu memberikan kontribusi dalam menyiapkan, merefleksikan, dan meningkatkan keinginan peserta didik untuk berpartisipasi aktif pada kampanye kepedulian lingkungan di kehidupan bermasyarakat tataran lokal, nasional, bahkan global. (Farris, 2012, dlm. 517; Kahn, 2010, hlm. XV: Stone dan Barlow, 2005, hlm. 111-115). 


\section{B. Rumusan Masalah}

Berdasarkan latar belakang masalah di atas, rumusan masalah dikemukakan dalam beberapa pertanyaan penelitian sebagai berikut:

1. Bagaimana puisi-puisi Kalimantan Selatan memberikan respon terhadap fenomena lingkungan alam?

2. Bagaimana strategi pengembangan nilai kesadaran lingkungan melalui puisi sebagai sumber pembelajaran Pendidikan IPS?

3. Bagaimana efektifitas puisi sebagai sumber belajar mampu menumbuhkan sikap kesadaran lingkungan peserta didik di SMP Negeri 6 Banjarmasin?

\section{Tujuan Penelitian}

Secara khusus tujuan penelitian ini adalah sebagaimana berikut:

1. Mendeskripsikan fenomena lingkungan alam yang direspon melalui puisi - puisi di Kalimantan Selatan.

2. Mendeskripsikan strategi pengembangan nilai kesadaran lingkungan melalui puisi sebagai sumber pembelajaran Pendidikan IPS

3. Menjelaskan efektifitas puisi sebagai sumber belajar untuk menumbuhkan sikap kesadaran lingkungan peserta didik di SMP Negeri 6 Banjarmasin

\section{Kajian Pustaka}

\section{Pengertian dan Muatan Pendidikan Lingkungan dalam IPS}

Menurut Maxim (2010, hlm. 8) dikemukakan bahwa Pendidikan Ilmu Pengetahuan Sosial (Social Studies) ialah "is a label for school subject that integrates, or brings together, the social sciences in a coordinated, systematic fashion to help young people become good citizens in culturally diverse, democratic society" adalah suatu sebutan untuk mata pelajaran sekolah yang mengintegrasikan, atau menyatukan, ilmu-ilmu sosial dalam terkoordinasi, secara sistematis untuk membantu orang-orang muda menjadi warga negara yang baik di beragam budaya, masyarakat yang demokratis. Menurut Somantri (2001, hlm. 92) dalam bukunya "Menggagas Pembaharuan IPS" berpendapat Pendidikan IPS adalah suatu penyederhanaan atau adaptasi dari disiplin ilmu-ilmu sosial dan humaniora serta kegiatan dasar manusia yang diorganisasikan dan disajikan secara ilmiah dan pedagogis atau psikologis untuk tujuan pendidikan". Farris (2012, hlm. 14) berpendapat bahwa PIPS "more than a collection of facts for children to memorize; it is an understanding of how people, places, and events came about and how people can relate and 
respond to each other's needs and desires" lebih dari kumpulan fakta untuk anak-anak untuk menghafal; merupakan pemahaman tentang bagaimana orang, tempat, dan peristiwa terjadi dan bagaimana orang dapat berhubungan dan menanggapi kebutuhan masing-masing dan keinginan.

Pendidikan IPS secara utuh melihat persoalan manusia tidak hanya dari segi perilaku tetapi juga dalam persfektif yang lebih luas yaitu kehidupan sosial dan alam. Konsep Ekologi dalam lingkungan sosial mengkaji secara khusus bagaimana interaksi masyarakat terhadap lingkungan hidup, yakni masyarakat menyadari perannya untuk menjaga, memelihara, mengembangkan, dan melestarikannya. Hubungan interaksi yang demikian dikemukakan oleh Barr, Barth, dan Shermis (1978) menjadi fokus konten materi ekologi dalam IPS (dalam Muhaimin, 2014, hlm. 33). Muatan pendidikan lingkungan dalam IPS sejalan dengan komitmen Pusat Kurikulum Kementrian Pendidikan Nasional (2010, hlm. 9-10) yang merumuskan nilai sikap peduli lingkungan sebagai bagian dari 18 nilai karakter bagi generasi muda.

Integrasi PIPS yang meramu pendidikan lingkungan didalamnya diharapkan memunculkan nilai kesadaran lingkungan. PIPS dapat memanfaatkan beraneka ragam situasi, pendekatan, serta sumber pembelajaran yang ada di lingkungan sekitar peserta didik. Sehingga, melalui pendidikan lingkungan mampu memberikan tekanan yang kuat pada kegiatan-kegiatan yang sifatnya praktis dan memberikan pengalaman secara langsung. Di masa yang akan datang, kesadaran lingkungan peserta didik dapat berguna untuk meneliti isu lingkungan yang utama dari sudut pandang lokal, nasional, regional dan internasional, sehingga peserta didik dapat menerima kondisi lingkungan di wilayah geografis yang lain (Palmer, 1998, hlm. 76).

\section{Pemanfaatan Puisi sebagai Sumber Belajar IPS}

Dalam bidang kesastraan (terutama puisi), menyajikan bagaiman nilai-nilai kehidupan disampaikan melalui alur berpikir yang runtut dengan pemakaian bahasa yang sesuai kaidah kebahasaan. Pada wacana postmodern karya seni tidak lagi dipandang sebagai karya artistik. Tetapi dipandang sebagai penyampaian nilai kehidupan melaui aspek tanda, jejak, dan makna. Dengan demikian, kajian-kajian estetika puisi pun menjadi meluas, tidak sebatas artefak yang disepakati sebagai karya seni, tetapi pada satu artefak yang mengandung makna. Objek nilai menjadi kajian estetika dibagi menjadi lima kajian diantaranya: fenomena alam, karya seni, seni design, filsafat seni, proses kreatif (pengalaman estetika). Suatu karya sastra disebut indah apabila organisasi unsur yang terkandung di dalamnya memenuhi syarat tertentu (Pradopo, 2012, hlm. 59-61; Waluyo, 1987, hlm. 70; Nurgiyantoro, 2005, hlm. 27). 
Puisi dalam konteks pemanfaatannya sebagai sumber belajar tidak dilakukan dengan cara yang seadanya. Secara khusus, sebelum menjadikannya sebagai sumber belajar, puisi harus dipilih berdasarkan kesesuaian tema yang diajarkan pada proses pembelajaran di kelas. Dalam penelitian ini, puisi yang digunakan hanyalah puisi kontemporer yang bertemakan lingkungan. Puisi kontemporer memiliki kias bahasa yang lebih mudah dipahami karena makna yang disampaikan sudah eksplisit. Sedangkan tema lingkungan dimaksudkan berdasarkan keseuaian materi pelajaran IPS yang diajarkan sehingga peserta didik dapat menapresiasi puisi dengan mudah.

Menurut Farris (2012, hlm. 487) "Poetry can play a large role in helping children understand a variety of topics, such us exploring concepts; money, justice, freedom, environment, egosentrism, etc". Puisi dapat memainkan peran besar dalam membantu anak memahami berbagai topik. Sebagaimana mengeksplorasi konsep-konsep; uang, keadilan, kebebasan, lingkungan, egosentrisme, dan lain-lain. Dalam bukunya, Farris tidak hanya menjelaskan bagaimana integrasi puisi sebagai sumber belajar IPS, tetapi juga mendeskripsikan implementasi dari puisi tersebut. Faktanya, anak-anak dapat memahami konsep yang dimaksudkan lebih baik karena anak-anak menjelaskan konsep berdasarkan pengalaman, pemahaman, dan imajinasi mereka. Oleh karena itu, puisi sebagai sumber belajar IPS dapat dijadikan sebagai inovasi pembelajaran IPS yang lebih menarik.

\section{E. Metodologi}

Rancangan dalam penelitian ini digunakan pendekatan metode campuran (mix methods). Penelitian mix method, khususnya pada pendekatan kualitatif digunakan untuk mengeksplorasi nilai-nilai puisi di Kalimantan Selatan dan dijadikan sebagai sumber pembelajaran dalam IPS. Namun, untuk melihat efektifitas puisi sebagai sumber belajar IPS sehingga meningkatkan kesadaran lingkungan peserta didik digunakan pendekatan kuantitatif. Dalam praktiknya, dua jenis aplikasi mix methods, yaitu; sequential (kombinasi berurutan) dan concurrent (kombinasi bersamaan/bercampur). Keduanya menghasilkan enam strategi berbeda. Akan tetapi dalam penelitian ini peneliti strategi yang digunakan adalah Sequential Exploratory Strategy.

\section{Fase Pertama}

Fase pertama merupakan penjabaran tahapan penelitian kualititatif yang dilakukan peneliti. Teknik penentuan sampel dalam fase ini bertujuan untuk (1) mendapatkan sebanyak mungkin data ataupun informasi dari berbagai sumber, (2) menggali data atau informasi yang akan yang 
menjadi dasar pemikiran. Adapun instrumen penelitian ialah peneliti sendiri. Menurut Lincoln dan Guba (1985:39) "Peneliti berperan sebagai human instrument yang secara penuh mengadaptasikan diri ke dalam situasi yang dimasukinya”. Sehingga proses penelitian sangat

penting dibandingkan hasil yang diperoleh". Fase pertama memiliki tiga langkah dalam teknik pengumpulan data, yaitu: observasi, wawancara, dan studi dokumentasi.

\section{Fase Kedua}

Fase kedua merupakan penjabaran tahapan penelitian kuantitatif yang dilakukan peneliti. Bentuk desain eksperimen yang digunakan merupakan pengembangan dari kuasi eksperimen atau eksperimen semu dengan menggunakan Posttest-Only Control Group Design. Dalam desain ini terdapat dua kelompok yang dipilih secara acak/random (R). Kelompok yang diberikan perlakuan disebut kelompok eksperimen yakni kelas VIII A dan kelompok yang tidak diberi perlakuan merupakan kelompok kontrol yakni kelas VIII B SMP Negeri 6 Banjarmasin. Kelompok eksperimen diberi perlakuan (treatment) dengan menerapkan puisi sebagai sumber belajar IPS, sedangkan kelompok kontrol tidak diberi perlakuan yang serupa. Tes akhir (posttest) diberikan pada dua kelas untuk mengetahui efektivitas perlakuan.

\section{F. Hasil dan Pembahasan}

\section{Gambaran Umum Kondisi Urang Banjar}

Masyarakat Banjar atau dikenal dengan sebutan Urang Banjar adalah penduduk yang mendiami wilayah Kalimantan Selatan. Pendapat mengenai gambaran umum Urang Banjar. dikemukan oleh Kiai Amir Hasan Bondan, yang menyatakan bahwa Urang Banjar menunjukan orang-orang yang mendiami wilayah Borneo Selatan tanpa dibatasi oleh dimensi waktu. Istilah ini juga juga menunjukan penduduk asli wilayah dan para pendatang diluar Kalimantan, seperti: Suku Jawa, Madura, Bugis, dan Melayu (Bondan.1953, hlm. 71). Dalam kajian historis menurut Ideham (2007, hlm. 69) Urang Banjar adalah sebutan yang diberikan oleh Dayak Ngaju kepada orang Melayu. Hal ini dikarenakan pada abad XIX terdapat sebuah kampung yang didiami oleh orang Melayu. Kampung tersebut dipimpin oleh orang Melayu bernama Pati Masih. Seiring berjalannya waktu, kampung tersebut disebut Banjar Olo Masih, yang berarti kampungnya orang Dayak dan dipimpin oleh Pati Masih. Secara keseluruhan Suku Banjar berjumlah 2.251.913 Jiwa (BPS Kalsel, 2013:41). Jumlah tersebut mencapai persentase 76,23\% dari keseluruhan suku yang mendiami Kalimantan Selatan. Adapun persebaran Urang Banjar mendiami daerah aliran sungai di Banjarmasin sampai Amuntai, dan daerah pahuluan atau pedalaman dari Banjarmasin, 
Martapura, Pelaihari, Rantau, Kandangan, Barabai, Amuntai, dan Tanjung. Adapun suku lain, antara lain: Suku Dayak, Bugis, Bajau, Mandar, Jawa, Bali, Arab, dan lain-lain.

Urang Banjar juga kental akan nilai-nilai Islam. Identitas keislaman yang melekat pada masyarakat Banjar tersebut sering dikaitkan dengan perjalanan historis yang dialami oleh masyarakat Banjar yang sangat terkait dengan sejarah berdirinya kerajaan Islam Banjar di kawasan ini. Oleh karena itulah, tidak mengherankan jika banyak karya yang mengulas hubungan Islam dengan masyarakat Banjar lebih dilihat dari perspektif historis. Penelusuran tentang asal usul etnik Banjar sebagaimana yang dipaparkan oleh Ideham (2007) menjadi acuan identitas keislaman Banjar. Cikal-bakal nenek moyang orang-orang Banjar adalah pecahan suku bangsa Melayu, yang sekitar lebih dari seribu tahun yang lalu, berimigrasi secara besar-besaran ke kawasan ini dari Sumatera atau sekitarnya Daud (2004, hlm. 128). Peristiwa perpindahan besar-besaran sukubangsa Melayu ini, yang belakangan menjadi inti nenek moyang suku bangsa Banjar, diperkirakan terjadi pada zaman Sriwijaya atau sebelumnya. Imigrasi besar-besaran dari sukubangsa Melayu tersebut kemungkinan sekali tidak terjadi dalam satu gelombang sekaligus. Ditambahkan pula oleh beliau, kemungkinan sekali etnik Dayak yang sekarang ini mendiami Pegunungan Meratus adalah sisa-sisa dari imigran-imigran Melayu. Dalam hal permukiman, bentuk perkampungan di lingkungan sungai selalu berpola linear mengikuti alur sungai tersebut dan rumah-rumah selalu menghadap ke sungai. Hingga sekarang di sepanjang sungai, khususnya Sungai Barito, Sungai Negara, Sungai Amandit, Sungai Martapura masih ditemui rumah-rumah penduduk yang dibangun diatas permukaan air yang dikenal dengan sebutan "lanting". Adapun Jaringan transportasi air merupakan bagian utama yang menjadi urat nadi dan pendorong tumbuh dan berkembangnya Kota Banjarmasin. Kota yang diperkirakan mulai berdiri pada perempat kedua abad ke-16 (Subiyakto, 1999, hlm. 38).

\section{Sorotan Penyair Lokal terhadap Fenomena Kerusakan Lingkungan di Kalimantan Selatan}

Puisi dalam konteks bahasannya merupakan bagian dari karya sastra imajinatif. Secara khusus, bagi penyair, puisi adalah sebuah wahana untuk untuk mengungkapkan ekspresi diri dalam balutan bahasa kias. Setiap kata-katanya banyak mengandung makna estetika yang terdiri dari berbagai elemen. Ekspresi batin yang dituangkan penyair pada karya sastra ciptaannya akan tereflesikan sebagai pantulan kembali masalah dasar di kehidupan manusia yang meliputi maut, cinta, tragedi, harapan, kekuasaan, kritik, pengabdian hingga tujuan hidup. Dengan demikian, 
setiap penyair tentunya akan memiliki sudut pandang berbeda terhadap permasalahan sosial yang mereka lihat (Pradopo, 2010, hlm. 44: Rusyana, 1984, hlm. 12: Nurgiantoro, 2013, hlm. 59).

Di Kalimantan Selatan, isu kerusakan lingkungan yang disorot oleh penyair lokal bukanlah hal baru. Bagi beberapa penyair lokal periode orde baru (hingga awal 2000) seperti Hijaz Yamani, Yustan Aziddin, dan D. Zauhiddie lingkungan alam adalah topik hangat yang tak lekang oleh waktu. Dalam buku yang berjudul "Tanah Huma" mereka mengemas permasalahan lingkungan di Kalimantan Selatan dengan sangat baik. Dalam aspek historis, dipahami bahwa masa orde baru, terjadi perubahan yang cukup dramatis dalam pola penyelenggaraan pembangunan. Penguatan basis kenegaraan yang sudah hampir rampung dipercepat oleh pemerintahan orde baru dengan menerapkan sistem sentralisasi kekuasaan. Di era orde baru keadaan hutan di wilyah Indonesia sangat subur, hal inilah yang kemudian menyematkan gelar bahwa hutan Indonesia merupakan paru-paru dunia. Akan tetapi, pasca eksploitasi besar-besaran hutan-hutan tersebut nampak tidak rimbun lagi. Praktis dengan penerapan sentralisasi, gejolakgejolak kecil yang masih tersisa dapat diredam, sehingga pemerintah fokus pada penyelenggaraan pembangunan. Berdasarkan tabel di bawah, berikut delapan puisi yang dipengaruhi oleh kenyataan fenomena lingkungan di Kalimantan Selatan yang digunakan dalam penelitian ini:

Tabel 4.1

Fenomena Lingkungan Pada Puisi

\begin{tabular}{|c|c|c|c|}
\hline Judul Puisi & Kutipan Bait & Pengarang & Periode \\
\hline $\begin{array}{l}\text { Huma yang } \\
\text { Perih }\end{array}$ & $\begin{array}{l}\text { Kemana perginya orang lumpur } \\
\text { Wajah tanah } \\
\text { Kaki yang kukuh dan tangan tak pernah } \\
\text { kering }\end{array}$ & D. Zauhiddie & \multirow{4}{*}{$\begin{array}{c}1960- \\
1980\end{array}$} \\
\hline $\begin{array}{l}\text { Kali } \\
\text { Martapura }\end{array}$ & $\begin{array}{l}\text { Kali Martapura airnya coklat } \\
\text { Mendesir-desir pada tepi lanting- } \\
\text { lanting*) tua } \\
\text { Banjarmasin kotaku di liku-likunya } \\
\text { Bertepi gedung-gedung pasar baru }\end{array}$ & Hijaz Yamani & \\
\hline $\begin{array}{l}\text { Awan } \\
\text { Berkaca }\end{array}$ & $\begin{array}{l}\text { Dipersolekkan wajahnya } \\
\text { Pijar lahar mengejar dan memeluk } \\
\text { Hangat api mengasapi angin jadi gelita } \\
\text { merah } \\
\text { Tanah berdada luka semburkan darah ke } \\
\text { tiap muka }\end{array}$ & $\begin{array}{l}\text { Yustan } \\
\text { Aziddin }\end{array}$ & \\
\hline Kepada & Ciumlah asap kota tapi jangan kau coba & Yustan & \\
\hline
\end{tabular}




\begin{tabular}{|c|c|c|c|}
\hline $\begin{array}{l}\text { Orang } \\
\text { Gunung }\end{array}$ & $\begin{array}{l}\text { mereguk } \\
\text { Dalam darahnya tertandak dosa semula } \\
\text { Aku yang membesar di sini ingin mati di } \\
\text { kakimu } \\
\text { Di tempat jadi kita hati benua }\end{array}$ & Aziddin & \\
\hline $\begin{array}{l}\text { Meratus } \\
\text { Berduka }\end{array}$ & $\begin{array}{l}\text { Pergantian abad millennium } \\
\text { Warnakan kedukaan } \\
\text { Meratus dilukai } \\
\text { Air matanya mengaliri } \\
\text { Melarutkan balai-balai } \\
\text { Tandik babalian } \\
\text { Tihang manteraku }\end{array}$ & $\begin{array}{ll}\text { Eko } & \text { Suryadi } \\
\text { WS } & \end{array}$ & \multirow{4}{*}{$\begin{array}{l}2000- \\
2013\end{array}$} \\
\hline $\begin{array}{l}\text { Kepada } \\
\text { Amandit }\end{array}$ & $\begin{array}{l}\text { Kepada Amandit } \\
\text { Kutitip sekeping harap } \\
\text { Jeramnya yang dalam jangan disumbat } \\
\text { dengan debu emas hitam } \\
\text { Desaunya nirmala rimbunnya jenggala } \\
\text { Jangan dikudapaksa dengan alasan niaga }\end{array}$ & $\begin{array}{l}\text { Hardiansyah } \\
\text { Ismail }\end{array}$ & \\
\hline $\begin{array}{l}\text { Meratus } \\
\text { Merintih }\end{array}$ & $\begin{array}{l}\text { Sekarang aku disulap dengan paksa } \\
\text { Dibabat dengan gergaji mesin } \\
\text { Dikeruk dengan traktor } \\
\text { Dibongkar dengan buldoser } \\
\text { Diangkut dengan tugboat } \\
\text { Untuk memenuhi napsumu }\end{array}$ & $\begin{array}{l}\text { Mansyah } \\
\text { Erpain }\end{array}$ & \\
\hline $\begin{array}{l}\text { Sungaiku } \\
\text { Menjerit }\end{array}$ & $\begin{array}{l}\text { Menjalar melata meraih ceruk kosong } \\
\text { Sampah menyembul, air hitam, bau } \\
\text { merebak } \\
\text { Di mana diriku, kenapa warnaku, } \\
\text { mengapa bauku, } \\
\text { Mana kawanku }\end{array}$ & $\begin{array}{ll}\text { Slamet Prih } \\
\text { Hariarti }\end{array}$ & \\
\hline
\end{tabular}

Dalam konteks faktual, fenomena tersebut mendeskripsikan bahwa kerusakan lingkungan di Kalimantan Selatan sudah memasuki tahap krisis. Beberapa data yang memperkuat alasan kenapa sorotan kerusakan lingkungan hanya berkutat pada tiga sektor, antara lain:

a Pada tahun 1967, guna merealisasikan esploitasi Sumber Daya Hutan (SDH), UndangUndang tentang Ketentuan-Ketentuan Pokok Kehutanan (UUPK) Nomor 5 Tahun 1967. Dalam konteks kajian kehutanan di daerah Kalimantan pada awal 1990an-2000. Berdasarkan data Forest Watch Indonesia (FWI) tahun 1990an mencatat bahwa kawasan hutan di Kalimantan Selatan yang tidak teralokasi tinggal 667.951 ha dari total wilayah Kalimantan Selatan dari tiga juta ha. Sisanya merupakan hutan terdegradasi dan hutan yang sudah gundul. 
Dari kondisi ini dapat dipahami bahwa penurunan wilayah hutan akibat perusahan perkayuan (termasuk illegal logging).

b Pada periode 2000an - sekarang, menurut Wahana Lingkungan (WALHI) masalah lingkungan yang disorot mengacu pada Pegunungan Meratus dan Sungai. Secara khusus, terpolusinya air sungai di Kalimantan Selatan diakibatkan oleh kegiatan-kegiatan warganya sendiri, seperti proses industri, penambangan, dan pembuangan tinja oleh warga di sekitar aliran sungai. Ditambahkan pula tahun 2008 sampai saat ini kondisi air sungai di Kalimantan Selatan dinilai sudah tercemar zat berbahaya bagi kesehatan manusia, yakni bisa merusak sel syaraf otak. Zat berbahaya itu antara lain logam berat seperti merkuri, timbal, besi dan air raksa (emas).

c Pada periode yang sama, eksploitasi ruang semakin meningkat. Semakin meluasnya kawasan pemukiman penduduk, permasalahan lingkungan dengan kasus eksploitasi ruang dapat dilihat dari wilayah Gambut. Wilayah yang awalnya merupakan lahan basah (rawa) berubah fungsi sebagai lahan kering akibat pengurukan tanah. Pengurukan lahan pertanian ini semakin menjadi karena perkembangan usaha bidang property yang ada di Gambut. Hal ini perlu mendapat perhatian yang sungguh-sungguh, karena fungsi lahan gambut sebagai resapan air telah mengalami perubahan yang sebaliknya, yang membuat wilayah Banjarmasin menjadi semakin rawan terjadi banjir yang lebih luas dan frekuensi yang semakin tinggi.

Selain fakta mengenai kerusakan lingkungan di Kalimantan Selatan, Kedelapan puisi yang digunakan dalam penelitian ini. menyampaikan tiga makna nilai kesadaran lingkungan. Adapun ketiga nilai tersebut, yaitu: (1) rasa syukur terhadap kesederhanaan wilayah pinggiran, (2) Sikap peduli terhadap kelangsungan Pegunungan Meratus, dan (3) Menjaga eksistensi Sungai bagi Urang Banjar. Pemaparan ketiga nilai yang terkandung dalam puisi-puisi tersebut sangat penting bagi peserta didik. Pengamalan ketiga nilai kesadaran lingkungan dalam pembelajaran IPS tidak hanya pada aspek pengetahuan, melainkan pada aspek sikap dan perilaku nilai tersebut dapat meningkatkan kepedulian akan permasalahan lingkungan yang ada di Kalimantan Selatan khususnya Banjrmasin.

\section{Strategi Pengembangan Nilai Kesadaran Lingkungan melalui Puisi sebagai Sumber Pembelajaran Pendidikan IPS}

Dalam menerapkan puisi sebagai sumber belajar IPS, menuntut guru IPS memperhatikan tiga hal, yakni: (1) tahapan implementasi, (2) keunggulan, dan (3) kendala yang muncul dalam 
pemanfaatan puisi sebagai sumber belajar IPS. Pertama, tahapan implementasi puisi sebagai sumber belajar IPS merupakan tahapahan yang diterapkan oleh guru agar pembelajaran IPS dengan puisi sebagai sumber belajar, tidak memunculkan kendala yang berarti. Adapun tahapan tersebut antara lain: memilih dan mengupas makna puisi, mengintegrasikan puisi ke dalam pembelajaran, menggunakan model pembelajaran kooperatif, dan menambahkan media audio visual dalam pembelajaran. Keempat tahapan implementasi dapat memudahkan guru IPS dalam memanfaatakan puisi. Hal ini dikarenakan setiap sub tahapan dapat meminimalisir kendala yang muncul saat dipraktikkan di kelas.

Praktik pemanfaatan puisi sebagai sumber belajar IPS di SMP Negeri 6 Banjarmasin dapat diidentifikasi bahwa terdapat keunggulan-keunggulan. Keunggulan ini dapat menjadi motivasi bagi guru-guru dan praktisi pendidikan IPS agar terus menggunakan puisi sebagai sumber belajar. Adapun keunggulan tersebut antara lain: a) Pengenalan Khazanah karya-karya Puisi Lokal, b) Menumbuhkan Kepekaan terhadap Permasalahan Lingkungan Sekitar, c) Meningkatkan Motivasi dan Pengalaman Peserta Didik, dan 4) Merangsang Kreatifitas Guru IPS. Keempat unggulan tersebut, secara bersamaan memunculkan kendala empat kendala sebagaimana yang dikhawatirkan pada tahapan implementasi. Keempat kendala yang dimaksud, yaitu: Kompetensi guru IPS, Apresiasi puisi oleh peserta didik, Pemilihan puisi lokal, dan Perumusan evaluasi pembelajaran. Seluruh tahapan di atas dimaksudkan agar evaluasi yang dilakukan tidak dirumuskan dengan sembarangan sehingga peserta didik dapat mendapatkan manfaat pembelajaran dengan sebaik mungkin.

\section{Efektifitas Puisi Lokal sebagai Sumber Belajar IPS guna Menumbuhkan Sikap Kesadaran Lingkungan Peserta Didik di SMP Negeri 6 Banjarmasin}

Sebagaimana dua fase tahapan penelitian yang digunakan, maka efektifitas puisi sebagai sumber belajar IPS dilihat dari fase kedua. Fase kedua menggunakan metode kuasi eksperimen. perbedaan yang muncul pada setiap pertemuan. Motivasi, komunikasi. Keaktifan, dan penguasaan materi pelajaran peserta didik di kelas eksperimen menunjukkan nilai positif. Bahkan dapat dikatakan ketiga aspek yang diobservasi terlihat stabil. Akan tetapi, di kelas kontrol dapat dilihat bahwa motivasi, komunikasi, efektifitas, dan penguasaan materi mengalami penurunan di pertemuan kedua. Secara tidak langsung, hal ini mempengaruhi nilai kesadaran lingkungan peserta didik di kelas kontrol. Secara khusus cakupan nilai kesadaran, terdiri dari tiga, antara lain: pengetahuan, sikap dan perilaku. Penjabaran hasil fase kedua untuk efektifitas 
puisi sumber belajar IPS untuk menumbuhkan nilai kesadaran lingkungan mencakup tiga aspek, yakni: pengetahuan, sikap dan perilaku. Ketiga nilai aspek dianalisis melalui olah SPSS 17. Keseluruhan data tiga aspek ini, berdistribusi tidak normal tetapi homogen. Berdasarkan hal tersebut, maka tiap analisis data dilakukan dengan uji independent $t$ test, berikut sajian data:

Tabel 4.2

Pengetahuan Tentang Lingkungan Hidup

\begin{tabular}{|l|c|c|c|c|}
\hline \multirow{2}{*}{ Kompetensi } & \multicolumn{2}{|c|}{ Kelompok } & \multirow{2}{*}{ Signifikansi } & Keterangan \\
\cline { 2 - 3 } & Eksperimen & Kontrol & \\
\hline $\begin{array}{l}\text { Pengetahuan } \\
\text { tentang } \\
\text { Lingkungan Hidup }\end{array}$ & 72,50 & 67,22 & $\begin{array}{c}0,011< \\
0,05\end{array}$ & Ada perbedaan \\
\hline
\end{tabular}

Tabel 4.3

Sikap Terhadap Lingkungan Hidup

\begin{tabular}{|l|c|c|c|c|}
\hline \multirow{2}{*}{ Kompetensi } & \multicolumn{2}{|c|}{ Kelompok } & \multirow{2}{*}{ Signifikansi } & Keterangan \\
\cline { 2 - 3 } & Eksperimen & Kontrol & & \\
\hline $\begin{array}{l}\text { Sikap Terhadap } \\
\text { Lingkungan Hidup }\end{array}$ & 76,28 & 71,67 & $\begin{array}{c}0,023< \\
0,05\end{array}$ & Ada perbedaan \\
\hline
\end{tabular}

Tabel 4.4

Perilaku Terhadap Lingkungan Hidup

\begin{tabular}{|c|c|c|c|c|}
\hline \multirow{2}{*}{ Kompetensi } & \multicolumn{2}{|c|}{ Kelompok } & \multirow{2}{*}{ Signifikansi } & Keterangan \\
\cline { 2 - 3 } & Eksperimen & Kontrol & & \\
\hline $\begin{array}{l}\text { Perilaku Terhadap } \\
\text { Lingkungan Hidup }\end{array}$ & 72,00 & 66,89 & $\begin{array}{c}0,023< \\
0,05\end{array}$ & Ada perbedaan \\
\hline
\end{tabular}

Tabel Pertama, secara empirik rata-rata pengetahuan tentang lingkungan hidup peserta didik dalam kelompok eksperimen lebih tinggi dibandingkan dengan kelompok kontrol. Dalam hal ini, nyatanya puisi sebagai sumber belajar IPS sangat relevan dijadikan media komunikasi guna memberikan Pengetahuan tentang lingkungan hidup di kelas eksperimen. Selain itu, puisi 
sebagai sumber belajar IPS dapat digunakan layaknya artikel dalam metode group investigation, sehingga dapat meningkatkan pengetahuan peserta didik. Tabel Kedua, rata-rata nilai sikap terhadap lingkungan hidup peserta didik dalam kelompok eksperimen lebih tinggi dibandingkan dengan kelompok kontrol. Puisi sebagai sumber belajar IPS secara emirik menghasilkan sikap peduli lingkungan yang didasarkan oleh nilai-nilai yang diyakini, dalam konteks nilai-nilai individu dan nilai-nilai ideal dalam sistem sosial masyarakat peserta didik. Tabel Ketiga, ratarata nilai perilaku terhadap lingkungan hidup peserta didik dalam kelompok lebih tinggi dibandingkan dengan kelompok kontrol. Puisi sebagai sumber belajar IPS secara empirik memberikan stimulus agar peserta didik memberikan partisipasi aktif dalam menjaga lingkungan sekitar. Selain itu, puisi sebagai sumber belajar IPS dapat menjembatani realitas permasalahan lingkungan kepada pembaca khususnya peserta didik untuk menjaga keberlangsungan lingkungan hidup.

\section{G. Simpulan dan Saran}

Secara keseluruhan, Puisi - puisi yang dibuat oleh penyair di Kalimantan Selatan khususnya yang bertemakan lingkungan sangat dipengaruhi pengalaman empirik penyair itu sendiri. Dalam penelitian ini puisi yang digunakan ada delapan dan terdiri dari dua generasi yang berbeda. Generasi pertama dipublish pada orde baru dengan penyair D. Zauhiddie, Hijaz Yamani, dan Yustan Aziddin. Generasi kedua, pasca reformasi dengan penyair Eko Suryadi WS, Hardiansyah Ismail, dan Slamet Prih Hariarti. Fenomena kerusakan lingkungan yang disorot oleh keenam orang tersebut pada dasarnya berada tiga sektor, yaitu (1) eksploitasi ruang, (2) eksploitasi Pegunungan Meratus, dan (3) kerusakan Sungai. Implementasi pemanfaatan puisi sebagai sumber belajar IPS di SMP Negeri 6 Banjarmasin mendapatkan sangat eleven untuk diterapkan di jenjang sekolah manapun. Kondisi faktual penerapan menggambarkan bagaimana antusiasme peserta didik di kelas eksperimen lebih baik dibandingkan di kelas kontrol. Perilaku sadar lingkungan di kelas eksperimen ditujukan dari kesadaran untuk merapikan suasana kelas sebelum pembelajaran dimulai. Peserta didik tidak menunggu instruksi dari guru. Kesadaran ini muncul dari diri sendiri. Selain itu, peserta didik menyoroti krisis ekologi yang terjadi di Kalimantan Selatan dengan kritis. Ragam argumen mewarnai jalannya diskusi di kelas eksperimen. Kondisi yang berbeda aada pada kegiatan pembelajaran di kelas VIII B sebagai kelas kontrol masih didominasi oleh pendekatan pembelajaran teacher center. Indikasi kejenuhan peserta didik di kelas kontrol nampak: 1) kurang bersemangat, 2) walaupun guru telah 
menggunakan infocus sebagai media pembelajaran, tetapi metode ceramah menjadi poros utama guru, 3) Materi guru hanya bersumber pada buku teks. Berkenaan hal tersebut saran yang ditujukan agar penelitian ini dapat terus diterapkan, antara lain:

1. Bagi penyair lokal, penting kiranya mendokumentasikan segala mahakarya yang dibuat ke dalam sebuah buku ataupun dokumentasi pribadi (portofolio). Dengan demikian, bagi siapapun yang memerlukan puisi tersebut untuk kepentingan pembelajaran dapat dilacak dengan mudah.

2. Sekalipun subjek penelitian ini adalah kelas VIII, tetapi alternatif sumber belajar IPS dengan menggunakan pendekataan sastra khususnya puisi relevan untuk diterapkan di kelas manapun pada jenjang Sekolah Menengah Pertama. Pada jenjang Sekolah Menengah Atas ataupun Sekolah Dasar. Hal terpenting yang harus dilihat oleh guru IPS adalah pemilihan puisi, agar penyampaian makna dapat dengan mudah dipahami.

3. Puisi sebagai sumber belajar IPS bagi guru IPS merupakan sebuah tantangan akan inovasi pembelajaran yang lebih komunikatif dan menarik.

4. Bagi akademisi di bidang Pendidikan Ilmu Pengetahuan Sosial agar dapat terus dikembangkan materi pembelajaran IPS melalui pendekatan sastra. Selain untuk menambah keragaman sumber belajar, hal ini dapat mengembangkan keilmuan IPS agar lebih kaya.

\section{DAFTAR PUSTAKA}

Bondan, Amir Hasan. (1953). Suluh Sedjarah Kalimantan.Banjarmasin: Fadjar

Creswell, John W. (2010). Research Design: Pendekatan Kualitatif, Kuantitatif, dan Mixed. Yogyakarta: Pustaka Pelajar

Chew, S. (2001). World Ecological Degradation: Accumulation, Urbanization, and Deforestation 3000 B.C.-A.D. Walnut Creek, CA: AltaMira.

Daud, Alfani. (2004). Islam dan Masyarakat Banjar: Deskripsi dan Analisa Kebudayaan Banjar. Jakarta: Raja Grafindo Persada

Departemen Pendidikan Nasional. (2010) Standar Kompetensi dan Kompetensi Dasar serta model silabus keterampilan bagi sekolah luar biasa. Jakarta: Depdiknas

Farris, J. Pamela. (2012). Elementary and Middle School Social Studies: An Interdisiplinary, Multicultural Approach. United State of America: Long Grove, Illions

Ideham, M. Suriansyah, dkk. (2007). Urang Banjar dan Kebudayaannya. Banjarmasin: Balitbangda dan Pustaka Banua

Komalasari, Kokom. (2011). Pembelajaran Kontekstual: Konsep dan Aplikasi. Bandung: Refika Aditama

Kementerian Pendidikan dan Kebudayaan (2013). Buku Guru Ilmu Pengetahuan Sosial. Jakarta: Kementerian Pendidikan dan Kebudayaan

Khan, Richard. (2010). Critical Pedagogy, Ecoliteracy, dan Planetary Crisis: The Ecopedagogy Movement. New York: Peter Lang 
Lincoln, Yvonna S. dan Guba, Egon G. (1985). Naturalistic Inquiry. London: Sage Publication, Inc

Maxim, George W. (2010). Dynamic Social Studies For Constructivist Classrooms:Inspiring Tomorrow's Social Scientists, Ninth Edition. USA:Pearson Education.Inc

Muhaimin. (2014). Pengembangan Model Problem Based Learning dalam Ecopedagogy untuk Peningkatkan Kompetensi Ekologis Mata Pelajaran IPS. Bandung: Disertasi (Tidak diterbitkan)

Nurgiantoro, Burhan. (2013). Sastra Anak: Pengantar Pemahaman Dunia Anak. Yogyakarta: Gadjah Mada University Press

Palmer, Joy A. (1998). Environmental Education In The 21 $1^{\text {st }}$ Century:Theory, Practice, Progress, and Promise. London and New York: Routledge

Palmer, Joy A. dan Philip Neal. (1994). The Handbook Of Environmental Education. London and New York: Routledge

Pradopo, Rahmat Djoko. (2010). Pengkajian Puisi. Yogyakarta; Gadjah Mada University Press

Sapriya. (2012). Pendidikan IPS: Konsep dan Pembelajaran. Bandung: Remaja Rosdakarya

Sanjaya, Wina. (2013). Strategi Pembelajaran Berorientasi Standar Proses Pendidikan. Jakarta: Prenada Media

Sugiyono. (2014). Metode Penelitian Kombinasi (Mixed Methods). Bandung; Alfabeta

Somantri, Muhammad Numan. (2001). Menggagas Pembaharuan Pendidikan IPS. Bandung: Remaja Rosdakarya

Stone, Michael K. dan Barlow, Zenobia. (2005). Ecological Literacy; Educating Our Children For Sustainable World. San Fransisco: Sierra Club Books

Trilling, Bernie dan Fadel Charles. (2009). $21^{\text {st }}$ Century Skills; Learning For Life in Our Times. United State Of America: Jossey-Bass

Waluyo, Herman J. (1987). Teori dan Apresiasi Puisi. Jakarta: PT Erlangga

Woolever, Robert dan Kathryn P.Scott. (1987). Active Learning In Social Studies: Promoting Cognitive And Social Growth. USA: Library of Congress Cataloging

Costanza et. al. (2007). "Sustainability or Collapse: What Can We Learn from Integrating the History of Humans and The Rest of Nature?". Swedia : Journal Ambio Vol.36, No.7 (November 2007)

Domanska, E. (2010). "Beyond Anthropocentrism in Historical Studies". USA: Journal Historein Vol. 10.

Kopnina, H. (2013). An Exploratory Case Study Of Dutch Children's Attitudes Toward Consumption; Implication for Environmental Education. The Journal Of Environmental Education. Volume 44, Issue 2, 2013

Bambang Subiyakto. (1999). Pelayaran Sungai di Kalimantan Tenggara. Tinjauan Historis tentang Transportasi Air Abad XIX. Yogyakarta: Tesis (tidak diterbitkan) Program Studi Sejarah, Jurusan Ilmu-ilmu Humaniora, Fakultas Pascasarjana, Universitas Gadjah Mada Yogyakarta 